\title{
Ethnologies
}

\section{Alaska's Women Pilots: Contemporary Portraits. By Jenifer Lee Fratzke. (Utah State University Press, 2004. Pp. xiv + 231, ill., photos, ISBN 0-87421-583-8)}

\section{Geoff Rayner-Canham}

Volume 31, numéro 1, 2009

Passages

URI : https://id.erudit.org/iderudit/038512ar

DOI : https://doi.org/10.7202/038512ar

Aller au sommaire du numéro

Éditeur(s)

Association Canadienne d'Ethnologie et de Folklore

ISSN

1481-5974 (imprimé)

1708-0401 (numérique)

Découvrir la revue

Citer ce compte rendu

Rayner-Canham, G. (2009). Compte rendu de [Alaska's Women Pilots:

Contemporary Portraits. By Jenifer Lee Fratzke. (Utah State University Press,

2004. Pp. xiv + 231, ill., photos, ISBN 0-87421-583-8)]. Ethnologies, 31(1),

271-274. https://doi.org/10.7202/038512ar

Ce document est protégé par la loi sur le droit d'auteur. L'utilisation des services d'Érudit (y compris la reproduction) est assujettie à sa politique d'utilisation que vous pouvez consulter en ligne.

https://apropos.erudit.org/fr/usagers/politique-dutilisation/ 
then the act of Whites speaking through a thin coat of blackness? Lhamon makes two statements that seem to contradict his method of analyzing the play's texts and deducing what the play's effect on the audience must have been. He says " 'you can't hear the yah! Yah!' of Jim Crow's underclass scoffing" (25). In another instance he says that Rice was aware that symbols mean different things to different audiences. Given these two statements by Lhamon, how can we know Rice's audiences without hearing from them?

While Lhamon states his awareness of the fact that Rice's plays were racist, this book lacks a discussion of why the "grotesquerie" of blackness was an effective tool against rich Whites. When Lhamon quotes Rice as saying he hoped black dandyism would "discourage the original in whites" the statement seems to speak about abhorrence of Blacks (23). As Lhamon says "Grotesquerie of Blacks is his vehicle not his target" (23). I wonder if these performances reinforced the perceived grotesquerie of the "vehicle".

Lhamon boldly reexamines and challenges popular ideas about a chapter of Atlantic history that others would rather ignore. While the effect that Rice had on the minds of his audience remains unproven, Lhamon is to be commended for pointing out that Rice's plays offered the first positive portrayals of Blacks in America's written history. This came at a time when other plays painted Blacks as pitiful and wretched. Most importantly, this book provides valuable insights into the early history of American white fascination with blackness, something that is at least as strong today as it ever was.

Jordan Mitchell Memorial University of Newfoundland $\mathcal{G}$ Labrador

Alaska's Women Pilots: Contemporary Portraits. By Jenifer Lee Fratzke. (Utah State University Press, 2004. Pp. xiv + 231, ill., photos, ISBN 0-87421583-8)

Flying has been - and still is - seen as a male profession. Yet there is every reason why women should make equally good pilots. In fact, it could be argued that women in general would make better pilots, tending to err on the side of caution rather than recklessness. Fratzke has added to the growing literature showing that women deserve their rightful 
place in the skies. She has chosen to focus on women pilots who have embraced the challenges of flying small planes (and helicopters) in the harsh climate of Alaska. Fratzke is well qualified to write this book, having flown in Alaska for seventeen years. In fact, through her stubbornness, Fratzke herself broke down some of the invisible barriers to women pilots in Alaska.

The book includes biographies of seven contemporary Alaska women pilots. However, it is much more than a biographical compilation. Fratzke writes the chapters in pairs: the first of each pair providing the context for each type of flying category. These categories are: commercial pilot; flight instructor; big game guide and bush pilot; private pilot; helicopter pilot; aerobatic pilot; and aviation safety inspector. The author also knows the historical background well; for example, the chapter on private pilots introduces the famous women pioneers of aviation, Harriet Quimby and Bessie Coleman.

Fratzke then cleverly leads each contextual account into how she became acquainted with each woman pilot whose biographical account follows in the second chapter of the pair. Each of these biographies provides an insight on how the woman developed an interest in flying. Then, illustrated by anecdotal stories and personal commentaries, we discover how each woman's flying career developed. The women pilots included in the compilation are Tamar Bailey, Noralie Jennings-Voigt, Ellie Jones-Elg, Sanna Green, Caroline Lachmann-Spivak, Darlene Dubay, and Val Aron Jokela. What comes through in each account is the overwhelming passion for flying, often in the face of male opposition which was, in many cases, petty, cruel, and vindictive. For example, Tamar Bailey commented how at night, wing covers and engine heaters and blankets had to be fitted over each plane. In bitter sub-zero (Fahrenheit) temperatures and strong winds, she had to struggle alone to protect her plane while the two male pilots would help each other with their planes and then walk off and leave her.

The experiences of these pioneering women mirror those in so many other fields. For example, Bailey's first attempt to break into commercial flying failed:

the woman [personnel manager on the hiring committee] downed me. The four pilots voted to hire me. And she said, "No, because she doesn't fit the profile." And she was exactly right. I didn't look like all those guys. I wasn't wearing the right clothes; I wasn't playing the game because I didn't know it was a game. 
So Bailey went to a classy department store in Anchorage and learned how to power dress and how to use makeup. Then with a woman pilot mentor, she succeeded in her goal.

Jennings-Voigt encountered the common viewpoint among males that all women are alike. "They weren't real enthused about having any women pilots because they'd had one before, and they said that she didn't quite work out as they wanted." She continued flying after the birth of her two children because "it was just that strong desire." As an instructor, she noticed a gender difference among her trainees: "Female students, of course being a little more cautious and conservative, still really want to learn. Women love to fly."

Males could be supportive or hostile. Jones-Elg had a tough male flying instructor but after only six hours flying experience, he insisted that she could solo despite her own self-doubt. The same instructor gave lessons to her husband. Her husband was incensed that it took him over twice as many hours of training before the instructor allowed him to go solo.

The tragic point bought out in Lachmann-Spivak's saga is that, to survive, women fliers have to adapt to the men's culture. She notes that: "I really get along with guys; I'm very comfortable around them." By contrast, she remarks: "Another gal came on board and they treated her like crud.... She was very shy, too. Real quiet." Lachmann-Spivak does not question why men have to set the rules of cockpit behaviour and mentally destroy those who do not play the "honorary male" role.

Bush flying is a very demanding occupation, often with unpredictable schedules, making it difficult to combine with a personal and family life. The pilot's biographies cover the range of single, married with children, or divorced. Jokela's poignant musings sum up the difficulty of combining an all-consuming career and the desire for companionship: "I'd like to find the right person again [her husband died] to settle down with.... But finding the right person gets harder the older you get.... The longer you go and you continue to grow, you've gotta find somebody that's also grown themselves and progressed. I'll tell you what, there's a lot of them out there that are not on a growth path at all."

What comes through, without exception, in each woman pilot's accounts is their enthusiasm for flying. This seems to be a common theme for women in so many careers (such as our own studies on pioneer women in science): that women develop a dedication, an almost religious 
devotion, to their vocation. Money is irrelevant; for each women flyer, all that matters is the thrill of pulling back on the joystick, lifting off the runway and having control of her metal bird as she soars into the skies.

These collective biographies show that women pilots have worked and flourished in one of the most unforgiving climates on the planet. As such, the volume fills a void in resources on women's careers. The book should be an inspiration to future young women pilots and, in particular, it might help them fight for gender-free skies. Finally, we would echo Fratzke's wish that the photos and accounts of these women find their rightful place in the Alaska Aviation Heritage Museum.

Geoff Rayner-Canham

Marelene Rayner-Canham Sir Wilfred Grenfell College

Memorial University

Comer Brook

The Scent of Eucalyptus: A Missionary Childhood in Ethiopia. By Daniel Coleman. (Fredericton, Goose Lane Editions, 2003. Pp. 254, ISBN 0864923740)

Like the eponymous tree in The Scent of Eucalyptus, Daniel Coleman's life in Ethiopia as a son of Canadian missionaries was that of a naturalized transplant. The fragrant eucalyptus tree played an ambiguous role in Ethiopia. Although it provided a sorely needed source of firewood when it was first introduced from Australia in the nineteenth century, the eucalyptus soon overstayed its welcome after it sapped nutrients out of the soil and native flora were unable to survive. Missionaries had come to that part of Africa in 1928 welcomed by the government of the time, and soon became part of the infrastructure by building medical and educational facilities. Yet they were among the first to be labelled as the enemy and subsequently ousted at times of political upheaval, arguably when they were most needed. This memoir captures the conflicting issues surrounding the relationship between missionary families and the country that they call home. 